\title{
Survival Rate of Sealed, Refurbished and Repaired Defective Restorations: 4-Year Follow-Up
}

\author{
Eduardo M. FERNÁNDEZ1 \\ Javier A. MARTIN ${ }^{1}$ \\ Pablo A. ANGEL ${ }^{1}$ \\ Ivar A. MJÖR ${ }^{2}$ \\ Valeria V. GORDAN ${ }^{2}$ \\ Gustavo A. MONCADA ${ }^{1}$ \\ ${ }^{1}$ Department of Operative Dentistry, Dental School, Universidad de Chile, Santiago, Chile \\ ${ }^{2}$ Department of Operative Dentistry, College of Dentistry, University of Florida, Gainesville, FL, USA
}

\begin{abstract}
The most common treatment in general dental practice is the replacement of restorations affected by secondary caries or marginal deficiencies. Alternative treatments to replacement of defective restorations, such as marginal sealing, refurbishment and repair, have demonstrated improvement of their clinical properties with minimal intervention. The aim of this clinical study was to estimate the median survival time (MST) of marginal sealing, repair and refurbishment of amalgam and resin-based composite restorations with localized defects as a treatment to increase the restoration longevity. A cohort of 66 patients, with 271 class I and II restorations clinically diagnosed with localized defects was longitudinally assessed. Each restoration was assigned to one of the following 5 groups: Marginal Sealing ( $\mathrm{n}=48)$, Refurbishment $(\mathrm{n}=73)$, Repair $(\mathrm{n}=27)$, Replacement $(\mathrm{n}=42)$, and Untreated $(\mathrm{n}=81)$. Two calibrated examiners assessed the restorations at baseline and annually during 4 years, using the modified Ryge criteria: marginal adaptation, anatomic form, roughness, secondary caries and luster. Fifty-two patients with 208 restorations were assessed after 4 years; the distribution of restorations in the groups was as follows: Marginal Sealing $(n=36)$, Refurbishment $(n=63)$, Repair $(n=21)$, Replacement $(n=28)$ and Untreated $(n=60)$. Kaplan Meier test indicated that the Sealed margins group showed the lowest MST while the Repair group showed the highest MST for restorations examined after 4 years of follow up. Defective amalgam and resin-based composite restorations treated by sealing of marginal gaps, refurbishment of anatomic form, luster or roughness, and repair of secondary caries lesions, had their longevity increased.
\end{abstract}

Key Words: operative dentistry, amalgam, resin based composites, restorations failures, alternative treatments.

\section{INTRODUCTION}

Replacement of defective restorations is the most common treatment in general dental practice. The main reasons for replacements are secondary caries and marginal defects (1-3). Subjective clinical criteria are used for replacement of restorations. It is well established that when a restoration is replaced, parts of healthy dental tissues are lost and the preparation is enlarged (4-6).

Alternative treatments to replacement of defective restorations, such as marginal sealing, refurbishment, and repair, have demonstrated improvement of the clinical properties for defective restorations with minimal intervention. Previous studies have established that simple procedures applied to posterior restorations significantly increased their quality and longevity $(5,7,8)$.
The aim of this prospective clinical trial is to estimate the median survival time (MST) of defective amalgam (AM) and resin-based composite (RBC) restorations that have been treated with either sealing, repair or refurbishment. The hypothesis was that sealing, refurbishing or repairing defective restorations increase their longevity with minimal intervention.

\section{MATERIAL AND METHODS}

A cohort of 66 patients, aged 18 to 80 years (mean age 26.5 years), with 271 defective $\mathrm{AM}(\mathrm{n}=193)$ and RBC $(n=78)$, Class I $(n=176)$ and Class II $(n=95)$ restorations that presented one or more clinical features deviating from the ideal were included (Bravo or Charlie, according with USPHS/Ryge criteria). All of them 
were recruited at the Operative Dentistry Clinic at the Dental School, University of Chile, Santiago, Chile. The protocol was approved by the local Research Ethics Committee and all patients signed informed consent forms and completed a registration form.

The inclusion criteria were: 1) patients with marginal deficiencies of $\mathrm{AM}$ and $\mathrm{RBC}$ restorations, which were clinically judged to be suitable for sealing, repair or refurbishment, according to the Ryge/USPHS criteria (Table 1); 2) patients with more than 20 teeth; 3) restorations in functional occlusion with an opposing natural tooth; 4) asymptomatic restored tooth; 5) At least one proximal contact area with a neighboring tooth; 6) patients older than 18 years; and 7) patients who agreed and signed the consent form for participating in the study.

The exclusion criteria were: 1) Patients with contra-indications for regular dental treatment based on their medical history; 2) patients who had special aesthetic requirements that could not be solved by the alternative treatments; 3) patients with xerostomia or who were taking medication that significantly decreased salivary flow; 4) patients with high caries risk, or 5) patients with psychiatric or physical diseases, which interfered with oral hygiene.

The restorations were assigned to one of five treatment groups - Marginal Sealing $(n=48)$, Refurbishment ( $\mathrm{n}=73$ ), Repair ( $\mathrm{n}=27)$, Replacement $(\mathrm{n}=42)$, and Untreated $(\mathrm{n}=81)$ - according to 4 criteria: 1. Restorations with marginal defects (Bravo) were randomly assigned to Marginal Sealing or Untreated group; 2. Restorations with clinically diagnosed secondary caries (Charlie) were randomly assigned to Repair or Replacement group. Diagnosis of active secondary caries was made according to Ekstrand's criteria (9); 3. Restoration with overcontoured anatomic form, luster or roughness defects, were randomly assigned to Refurbishment (Bravo and Charlie) or Untreated group (Bravo); 4. Restorations with undercontoured anatomical form defects (Bravo), were randomly assigned to Repair or Replacement group. Randomization was done by Power Analysis and Sample Size System (PASS software v. 2008, Keysville, UT. USA).

The quality of the restorations was rated according to the modified U.S. Public Health System/Ryge criteria (10). Two independent calibrated examiners Cohen's Kappa 0.67 at baseline (immediately after treatment) and 0.87 at 4 years - assessed all restorations. Examinations were done directly, by visual and tactile modes, using mouth mirror number 5 (Hu Friedy Mfg. Co. Inc., Chicago, IL, USA) and explorer number $23 \mathrm{Hu}$ Friedy), and indirectly, by the analysis of bitewing radiographs at baseline and 1, 2, 3 and 4 years after treatment. The 5 examined parameters were: marginal adaptation, anatomic form, roughness, secondary caries and luster. If any difference was recorded 
between the 2 examiners, and if they did not reach an agreement, a third calibrated clinician was called to make the final decision. Description of the treatment groups is given in the following paragraphs.

Marginal Sealing group. This group involved the application of a sealant in small and localized marginal restoration gap. The defective margins were acid etched with $35 \%$ phosphoric acid for $15 \mathrm{~s}$. A resin based sealant (Clinpro Sealant, 3M ESPE, St. Paul, MN, USA) was applied over the defective area. The sealant was polymerized with a light cured unit (Elipar Curing Light, 3M ESPE) during $20 \mathrm{~s}$. Rubber dam isolation was used during this procedure.

Refurbishment group. This group involved the resurfacing or removal of any excess of material and the reshaping of the anatomic form $(4,7,8)$, by contouring and finishing the occlusal, lingual or facial surfaces of defective restorations. Defective areas of the AM restoration were smoothed using carbide burs (12 and 30 blades, Brasseler, Savannah, GA, USA). On occlusal and bucal/lingual surfaces, silicone impregnated points were used for polishing (Brownie/Greenie/Supergreenie, Shofu Dental Corporation, Menlo Park, CA). The defective areas of the $\mathrm{RBC}$ restorations were polished with medium series of aluminum oxide disks or carbide burs followed by a fine series of aluminum oxide polishing disks (Sof-Lex. 3M ESPE) and impregnated points (Diacomp polishing point, Brasseler). The defective areas were smoothed with interproximal aluminum oxide finishing strips (Sof-Lex, 3M ESPE) if the interproximal area was affected.

Repair group. Repair was defined as the removal of part of the restoration, along with the localized defect and restoration of the prepared site. For repair, carbide burs (330-010) were used to explore the defective margins of the restorations, beginning with the removal of restorative material adjacent to the defect. Once this material was removed, an exploratory cavity preparation included any demineralized and soft tooth tissue. A dispersed phased AM (Original D; Wykle Research, Inc Carson City, NV, USA) was used to repair the AM restoration. Mechanical retentions were created inside the existing restoration. For RBC restorations, a self priming resin bonding system was used (Adper Promp L-Pop; 3M ESPE) followed by restoration with RBC restorative material (Filtek Supreme; 3M ESPE). Rubber dam isolation was used for this procedure.

Replacement group. The defective restoration was totally removed and replaced by either AM (Original D) or RBC (Filtek Supreme; 3M ESPE) restoration under rubber dam isolation. The elimination of soft tooth tissue caries infected was done using a carbide burs at high speed under full water irrigation. During cavity preparation, no preventive extension or undercutting areas were designed, and all cavity angles were rounded. In deep dentin, a glass ionomer liner were used (Vitrebond; 3M ESPE; USA). Cavity was treated by Adper Promp L-Pop, (3M ESPE) according to manufacturer's instructions; finally RBC (Filtek Supreme; 3M ESPE) was applied by incremental technique. Occlusion was checked and restorations were finished and polished according to manufacture instructions.

Untreated group. No treatment was provided and the restorations were monitored visually and used as a negative control group.

All patients were recalled annually for clinical evaluation of the restorations by the same blinded examiners, using the same criteria used at baseline. Calibration exercises among the examiners preceded all annual evaluations. A change from Alfa to Bravo was considered a deterioration of the restoration and a change from Bravo to Alfa was considered an improvement.

Failed restorations were removed from the study and treated according to their diagnosed requirements. The data were analyzed using the Kaplan Meier test to determine the MST, defined as the time from the treatment at which half of the restorations are still in Alfa state for each parameter, and by chi-square nonparametric pairwise comparisons test to contrast the pre and post operative conditions, at $\alpha=0.05$ (SPSS v.15.01; SPSS Inc., Chicago, IL, USA).

\section{RESULTS}

From the original cohort of 66 patients (271 restorations), 52 patients (78.8\%) were evaluated after 4-years with 208 restorations (76.7\%): class I $(n=139)$ and class II $(n=69)(R B C n=58$ and $A M n=150)$. The distribution of restorations in the groups was as follows: Marginal Sealing ( $\mathrm{n}=36)$, Refurbishment $(\mathrm{n}=63)$, Repair $(n=21)$, Replacement $(n=28)$ and Untreated $(n=60)$.

At the 4-year recall, 63 restorations had been lost to follow up due to patient drop out, orthodontic reasons (metallic band covered the restorations), endodontic retreatment, and traumatic accident. The results are presented as Kaplan Meier Curve showing the MST (Figs. 1 to 5). MST of Alfa-rated restorations in the different groups s given in Table 2 . 
All groups showed a trend to downgrade during the observation period. Initially defective restorations upgraded to Alfa rating, but showed a return to Bravo and remained in that condition for the 4 years. Charlie condition was present only in a small number of restorations: Marginal adaptation 3.4\%, roughness 1.9\% and luster $2.9 \%$.

The Kaplan Meier test indicated that the Marginal Sealing group showed a MST of 3 years for the parameter marginal adaptation, with no significant differences ( $>0.05$ ) when compared to the Replacement and Untreated group. The Repair group presented the worst performance, with a MST of 2 years, significantly lower when compared to any other group $(\mathrm{p}<0.05)$.

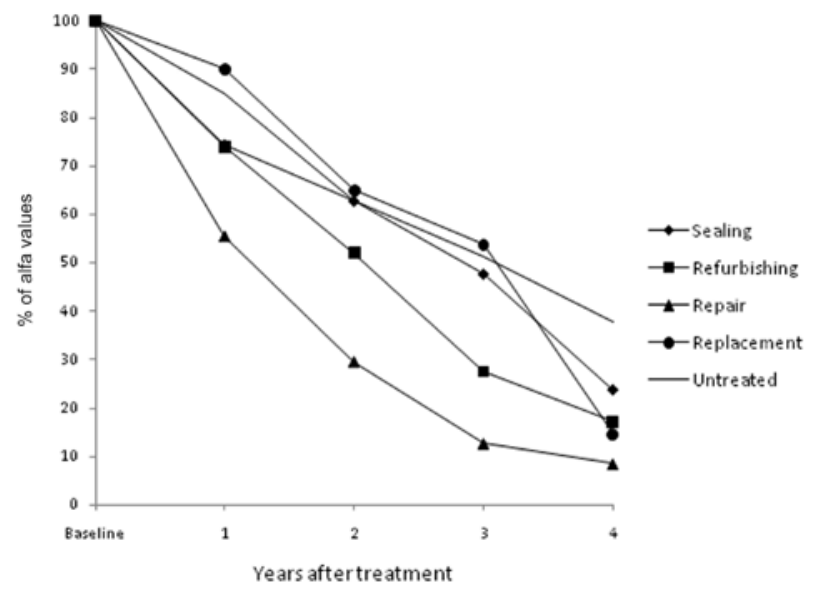

Figure 1. Marginal adaptation. Kaplan Meier survival curve showing the median survival time of the restorations (Alfa rating) of all groups at each of the 4 years of follow up.

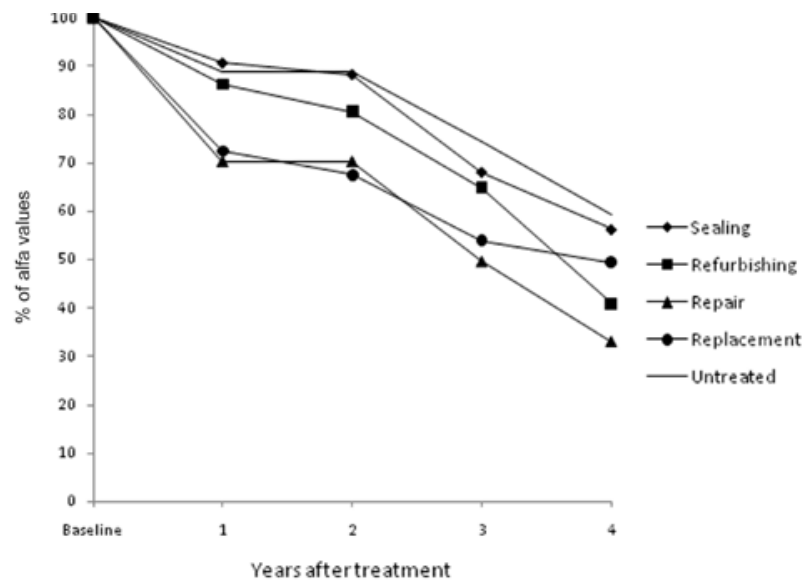

Figure 3. Surface roughness. Kaplan Meier survival curve showing the median survival time of the restorations (Alfa rating) of all groups at each of the 4 years of follow up.
The refurbishing treatment showed a good performance for the handling of roughness defects, with statistically significant differences only from the Untreated group $(\mathrm{p}<0.05)$, but the results of this treatment were not so good for handling luster of restorations. For the parameter roughness, the Repair group presented the worst performance, differing significantly from the Marginal Sealing and Untreated groups $(p<0.05)$, while for the luster parameter, the Replacement and Untreated group showed longer MST than that of the Refurbishment group $(\mathrm{p}<0.05)$.

Comparison of Repair and Replacement groups for the parameters secondary caries showed no statistically differences in the MST. For this parameter, all treatment groups exhibits a MST of more than 4 years.

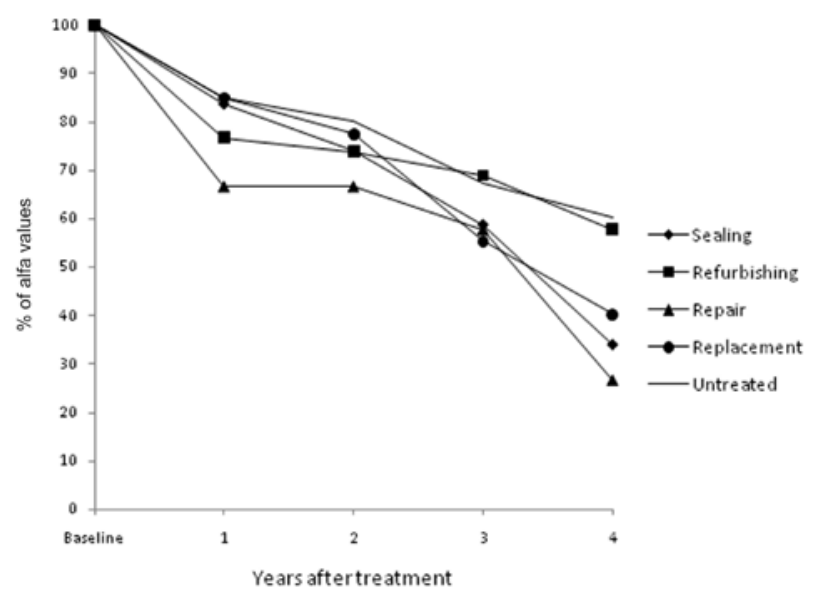

Figure 2. Anatomic form. Kaplan Meier survival curve showing the median survival time of the restorations (Alfa rating) of all groups at each of the 4 years of follow up.

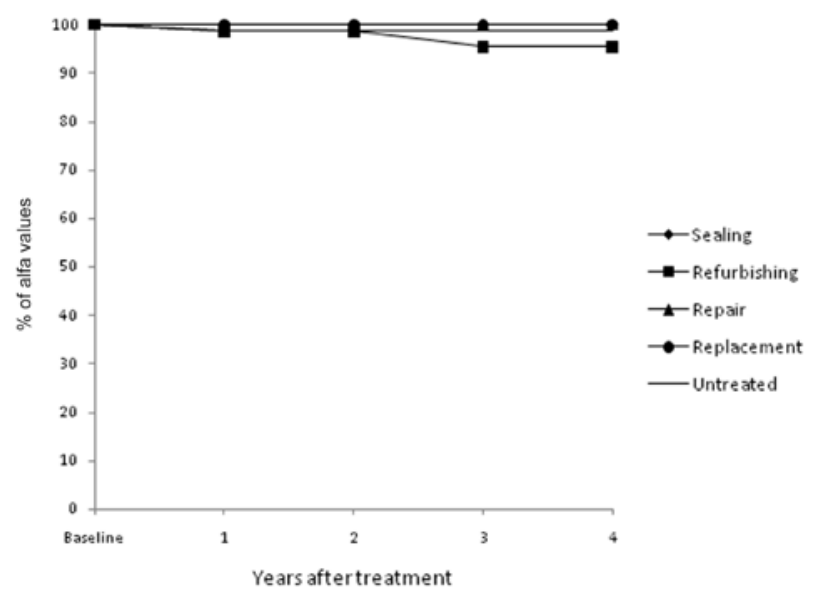

Figure 4. Secondary caries. Kaplan Meier survival curve showing the median survival time of the restorations (Alfa rating) of all groups at each of the 4 years of follow up. 


\section{DISCUSSION}

The longevity of restorative treatments is relevant information for government, patients, and dentists in order to clarify and plan the cost of dental restorations. New programs using alternative treatments that may be less invasive should be considered.

The results of this clinical study accepted the hypothesis that alternative treatments to replacement of defective restorations increase the longevity of restorations with minimal intervention. This study presents the MST of the 3 alternative clinical procedures and based on the results, it is possible to associate the type of treatment and prognosis of each procedure. For optimal clinical decision of treatment is necessary to identify patient's caries risk, restorative treatment and material. In that context, alternative treatments open a minimally invasive treatment option to restore defective restorations $(4,7,8,11)$.

The results of this present study support that clinical decision should be thought out prior to the selection of alternative treatment. During the 4-year period, few restorations failed, with no tooth fractures. No pulp injury was observed during the 4 years of observation, which could be explained by the low traumatic technique and by the use of techniques involving cavity preparations under copious abundant water spray (12).

This study support the idea there are other treatment options to replacement of restorations that are less time-consuming, with easier application, and less biological risk for the teeth $(13,14)$.

The most frequently reported reason for

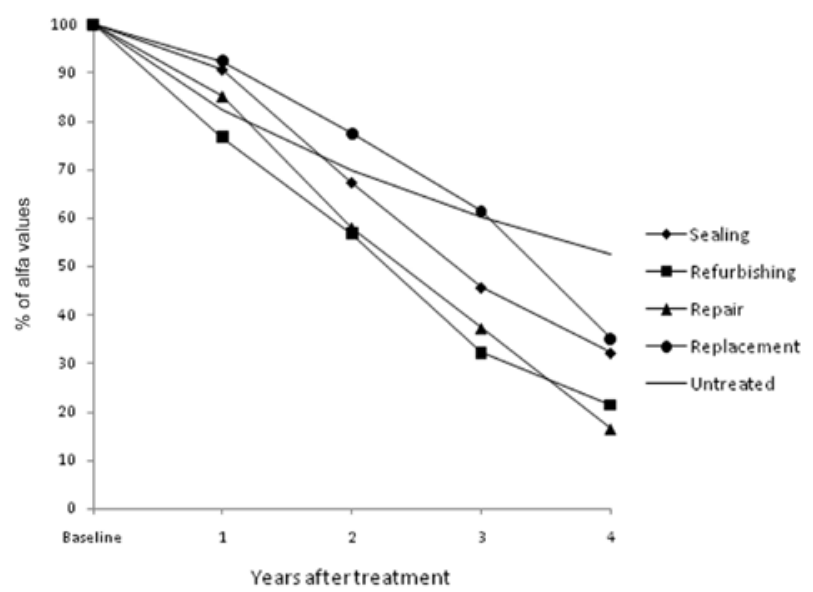

Figure 5. Luster. Kaplan Meier survival curve showing the median survival time of the restorations (Alfa rating) of all groups at each of the 4 years of follow up. replacement of restorations is secondary caries (1-3), and the decision os invariably for the total replacement of the restoration. Repair of those restorations showed a MST of more than 4 years. In the present study a low number of teeth developed secondary caries lesions (1.4\%).

Other reasons for replacement include marginal defects. When defective margins are sealed, it is possible to expect a MST of 3 years. When anatomic form defects are present, it is likely that the MST of the restorations treated by refurbishment would be more than 4 years. The majority of studies reporting the longevity of AM and RBC restorations show MST rates of 6 to 10 years. With that in mind, the alternative treatments studied represent an important contribution to restoration longevity as most of the restorations are functioning well with no need of replacement of the defective restorations $(1,15)$.

The downgrade from Alfa to Bravo was used to determine the MST of the alternative treatments. It must be recognized that a Bravo rating does not mean that the restorations must be replaced. The present results confirm that a Bravo rating for clinical characteristics other than marginal integrity and anatomical form do not need to be immediately replaced (4).

Additionally, the results confirm that when localized defects are present, alternative treatments slow down the process of failure without necessarily avoiding the downgrade of restorations. The downgrade observed here could be due to other variables involving individual clinical characteristics, such as size and cavity depth, patient's caries risk, occlusion, bruxism, relationship with periodontal tissues or other features, which might explain some of the deterioration if further explored.

A recent in vitro study (16) showed that it is possible to increase the mechanical strength in repaired AM restorations, when AM surface is first silica coated,

Table 2. Median survival time (in years) of Alfa-rated restorations according to the groups and parameters (USPHS/Ryge criteria).

\begin{tabular}{lccccc}
\hline Group & MA & AF & R & SC & L \\
\hline Marginal Sealing & 3 & 4 & $>4$ & $>4$ & 3 \\
Refurbishment & 3 & $>4$ & 4 & $>4$ & 3 \\
Repair & 2 & $>4$ & 3 & $>4$ & 3 \\
Replacement & 4 & 4 & 4 & $>4$ & 4 \\
Untreated & 4 & $>4$ & $>4$ & $>4$ & $>4$ \\
\hline
\end{tabular}

$\mathrm{MA}=$ marginal adaptation; $\mathrm{AF}=$ anatomic form; $\mathrm{R}=$ roughness; $\mathrm{SC}=$ secondary caries; $\mathrm{L}=$ luster. 
then the dentin-enamel surface is etched and AM is silanized before primer and bonding is applied onto the dentin. Clinical confirmation, however, is needed.

Future research in composite repair could test the role of biofilm over aged restorations. Recently, Rinastiti et al. (17) found that in vitro exposure to oral biofilm is a clinically relevant aging condition and that silica-coating should be preferred for the repair of aged composites.

A retrospective study (18) showed no significant differences in survival rates between repaired and replaced AM restorations at 5 years, though repaired AM restorations showed higher failure rate after 10 years. However, it is not always easy to determine the best treatment option in routine dental treatments, the results confirm that alternative treatments should be considered as they offer improvement to the clinical condition of restorations with minimal intervention.

In conclusion, defective $\mathrm{AM}$ and $\mathrm{RBC}$ restorations treated by sealing of marginal gaps, refurbishment of defective anatomic form or removal of localized areas affected by secondary caries presented a reasonable MST. Significant increase in the clinical longevity is achieved with minimal intervention and no need for full replacement of defective restorations.

\section{RESUMO}

Na clínica odontológica geral, o tratamento mais comum é a substituição de restaurações com cárie secundária ou defeitos marginais. Tratamentos alternativos às substituições de restaurações defeituosas, como selamento marginal, recuperação, e reparo, têm proporcionado melhorias das propriedades clínicas, com um mínimo de intervenção. O objetivo deste estudo foi avaliar o tempo médio de sobrevida (median survival time - MST, na sigla em inglês) de selamento marginal, recuperação e reparo de restaurações de amálgama e compósitos resinosos com defeitos localizados, como tratamento para aumentar a longevidade das restaurações. Este foi um estudo longitudinal envolvendo 66 pacientes com 271 restaurações classe I e II, clinicamente diagnosticadas e com defeitos localizados. Cada restauração foi incluída num dos seguintes grupos: Selamento Marginal $(n=48)$, Recuperação $(n=73)$, Reparo $(n=27)$, Substituição $(n=42)$ e Sem tratamento $(n=81)$. Dois examinadores calibrados avaliaram as restaurações no início e anualmente durante 4 anos, usando os critérios de Ryge modificados: adaptação marginal, forma anatômica, rugosidade, cárie secundária e brilho. Cinqüenta e dois pacientes com 208 restaurações foram avaliados após 4 anos; a distribuição das restaurações nos grupos foi a seguinte: Selamento Marginal (n=36), Recuperação ( $n=63)$, Reparo ( $n=21)$, Substituição $(n=28)$ e Sem tratamento $(n=60)$. O teste de Kaplan Meier mostrou que o grupo do Selamento Marginal apresentou o menor valor de MST, enquanto que o grupo do Reparo mostrou o maior valor, para as restaurações avaliadas após o acompanhamento de 4 anos. As restaurações de amálgama e compósitos tratadas com selamento de fissuras marginais, recuperação da forma anatômica, brilho ou rugosidade e reparo de cárie secundária, tiveram aumento de longevidade.

\section{ACKNOWLEDGEMENTS}

Study ascribed to project PRI-ODO 0207 Universidad de Chile.

\section{REFERENCES}

1. Hickel R, Manhart J. Longevity of restorations in posterior teeth and reasons for failure. J Adhes Dent 2001;3:45-64.

2. Mjör IA, Moorhead JE, Dahl JE. Reasons for replacement of restorations in permanent teeth in general dental practice. Int Dent J 2000;50:361-366.

3. Mjör IA. Placement and replacement of restorations. Oper Dent 1981;6:49-54.

4. Gordan VV, Riley JL 3rd, Blaser PK, Mjör IA. 2-year clinical evaluation of alternative treatments to replacement of defective amalgam restorations. Oper Dent 2006;31:418-425.

5. Gordan VV. Clinical evaluation of replacement of class V resin based composite restorations. J Dent 2001;29:485-488.

6. Gordan VV. In vitro evaluation of margins of replaced resin-based composite restorations. J Esthet Dent 2000;12:209-215.

7. Moncada G, Martin J, Fernandez E, Hempel MC, Mjör IA, Gordan VV. Sealing, refurbishment and repair of Class I and Class II defective restorations: a three-year clinical trial. J Am Dent Assoc 2009; 140:425-432.

8. Moncada G, Martin J, Fernandez E, Vildósola P, Caamano C, Caro MJ, et al.. Alternative treatments for resin-based composite and amalgam restorations with marginal defects: a 12 -month clinical trial. Gen Dent 2006;54:314-318.

9. Ekstrand KR, Kuzmina IN, Kuzmina E, Christiansen ME. Two and a half-year outcome of caries-preventive programs offered to groups of children in the Solntsevsky district of Moscow. Caries Res 2000;34:8-19.

10. Cvar J, Ryge G. Criteria for the clinical evaluation of dental restorations materials, in 1971, US Public Health Service: San Francisco.

11. Moncada G, Fernandez E, Martin J, Arancibia C, Mjör IA, Gordan VV. Increasing the longevity of restorations by minimal intervention: a two-year clinical trial. Oper Dent 2008 33:258-264.

12. Mjör IA. Dentin permeability: the basis for understanding pulp reactions and adhesive technology. Braz Dent J 2009;20:3-16.

13. Tyas MJ, Anusavice K, Frencken JE, Mount GJ. Minimal intervention dentistry - a review. Int Dent J 2000;50:1-12.

14. Mjör IA. Repair versus replacement of failed restorations. Int Dent J 1993;43:466-472.

15. Downer M, Azli N, Bedi R, Moles D, Setchell D. How long do routine dental restorations last? A systematic review. Brit Dent J, 1999; 187: 432-439.

16. Ozcan M, Schoonbeek G, Gokce B, Comlekoglu E, Dundar M. Bond strength comparison of amalgam repair protocols using resin composite in situations with and without dentin exposure. Oper Dent 2010;35:655-662.

17. Rinastiti M, Ozcan M, Siswomihardjo W, Busscher HJ, van der Mei HC. Effect of biofilm on the repair bond strengths of composites. J Dent Res 2010;89:1476-1481.

18. Smales RJ Hawthorne WS. Long-term survival of repaired amalgams, recemented crowns and gold castings. Oper Dent 2004;29:249-253. 